\title{
Motion Response Analysis of Hexagonal Pontoon Wave Energy Converter
}

\author{
Irfan Arief Syarief ${ }^{1}$, Achmad Baidowi $^{2}$, Azzahra Nirwana Islami ${ }^{3}$ \\ (Received: 01 August 2019 / Revised: 18 June 2020 / Accepted: 25 June 2020)
}

\begin{abstract}
- the wave energy conversion system is one of the technology innovative used in the researches of alternative power plants at sea. It receives environmental loads such as wave, wind, and current during its operation. In order to be able to rotate the pendulum and produce electricity, it is designed with a hexagonal-shaped ponton with three floaters on its sides to increase the rotational motion of the ponton. These floaters are connected to the ponton by the arm, identically distant from one another. The mooring system used in this research is designed to allow it to still move and rotate the pendulum while keeping the platform from capsizing. This research is discussing the difference of motion response between three variations of wave energy conversion system designs, Variation 1 that is designed with floaters, Variation 2 with shortened floater arms, and Variation 3, which have no floaters, by comparing their RAOs (Response Amplitude Operator), to figure out which design is the most responsive when the collinear load from heading $0^{\circ}, 30^{\circ}, 6^{\circ}, 90^{\circ}$, and $120^{\circ}$ is acting on it. This research reveals that model Variation 1 is the most optimal because it has relatively higher values of RAOs, and the motion response of the ponton is still apparent after the mooring system is installed. The highest RAO in free-floating condition for 6 degree of freedom surge, sway, heave, pitch, roll, and yaw are $1,949 \mathrm{~m} / \mathrm{m}$ frequency $0,1 \mathrm{Rad} / \mathrm{s} \mathrm{heading} 0^{\circ}, 1,6 \mathrm{~m} / \mathrm{m}$ frequency $1,7 \mathrm{Rad} / \mathrm{s}$ heading $60^{\circ}, 0,998 \mathrm{~m} / \mathrm{m}$ frequency $0,1 \mathrm{Rad} / \mathrm{s}$ heading $0^{\circ}, 22,13 \mathrm{Deg} / \mathrm{m}$ frequency $1,8 \mathrm{Rad} / \mathrm{s} \mathrm{heading} 60^{\circ}, 21,7 \mathrm{Deg} / \mathrm{m}$ frequency $2 \mathrm{Rad} / \mathrm{s}$ heading $0^{\circ}$, and 77,212 $\mathrm{deg} / \mathrm{m}$ frequency $1,8 \mathrm{deg} / \mathrm{m}$ heading $0^{\circ}$ consecutively. The furthest excursion is at 5,1 meters along with the $x$-axis $0^{\circ}$ load, while the shortest excursion is 1,5 meters along with the $y$-axis $120^{\circ}$ load. The highest Roll motion reached $62,5^{\circ}$ along the $x$-axis $90^{\circ}$ load while pitch motion reached $15,5^{\circ}$ along with the $y$-axis $120^{\circ}$ load.
\end{abstract}

Keywords - hexagonal ponton, motion, rao, wave energy conversion system.

\section{INTRODUCTION}

$\mathrm{F}$ ossil fuels such as crude oil, coal, and natural gases have been the main resource used for energy and power plant. Although technology keeps developing, there are still many negative effects due to the excessive extraction of these natural resources [1]. Numbers of alternative renewable resources such as water, wind, solar energy, and many more have been found [2].

There are three types of ocean energy potentials, the tidal power, the wave energy, and the ocean thermal energy [2]. One of the already existing ocean energy power plant is the wave generated power plant with a pendulum system invented and developed by Zamrisyaf, a researcher at the center of research and development of Perusahaan Lisrik Negara (PLN) together with Institut Teknologi Sepuluh Nopember (ITS) Surabaya since 2002. This power plant operates by utilizes a ponton that acts as a floating structure. This ponton is carrying the pendulums that are integrated into a dynamo. The pendulums are assisted with a double freewheel transmission equipment to make the dynamo rotates. Thus, electricity is produced. Due to the dependency of the energy produced to the movement of the pendulums, the design of ponton, type of wave, and environmental factors of where the ponton is

Irfan Syarief Arief, Departement of Marine Engineering, Institut Teknologi Sepuluh Nopember, Surabaya, 60111, Indonesia. E-mail : irfansya@gmail.com

Achmad Baidowi, Departement of Marine Engineering, Institut Teknologi Sepuluh Nopember, Surabaya, 60111, Indonesia. E-mail : ahmadbai@gmail.com

Azzahra Nirwana Islami, Departement of Marine Engineering, Institut Teknologi Sepuluh Nopember, Surabaya, 60111, Indonesia. Azzahranirwana14@gmail.com installed are the most effective factors on the movement of the ponton [1].

Mooring system installation is required to keep the unit stays in its appropriate working station and also to prevent it from exceeding the maximum excursion of the ponton [3] [4] [5]. Thus, the flexibility in a certain mode of motion required to improve the energy extraction is provided, and the operability of the unit can be maintained. Therefore, motion analysis needs for variations of designs with the pontoon is conducted in order to find the most effective design for the wave energy conversion system [6]. The analysis is done in motion analyzing numerical software to find out the effect of pontoon design variation with floaters and without floaters to the motion response of the pontoon.

\section{A. Wave Energy}

The dependency on fossil fuels has become harmful because of the continuous extraction and the unsustainability of fossil fuel. Therefore, alternative energy from a renewable resource is in high demand. Wave energy is one of them. Wave energy is divided into three different categories, ocean wave energy, ocean current energy, and ocean thermal energy.

\section{B. Wave Generated Power Plant}

There are three major types of wave energy conversion devices based on how they interact with the ocean wave. The first one is the Oscillating Water Columns (OWC). OWCs are devices that involve a structure on the shoreline in which the waves enter and leave a static chamber. The motion of the water pushes air up when it enters and pulls air back as it leaves. This oscillation of air pressure rotates the integrated turbine to generate electricity. 
The second one is the Overtopping Devices (OTD) that consist of a structure that elevates the wave into a reservoir placed above the sea level [7] [8]. The energy is then extracted by using the difference in water level between the reservoir and the sea. The difference in the water level is measured using a low head Kaplan turbine.

The last one is the wave activated bodies (WAB) that directly utilizes the motion of the ocean surface [9] [10]. They generally involve floating structures that move up and down due to the buoyancy force of waves. The energy is extracted from the relative motions of the structures relative to its fixed reference by using a hydraulic system to compress oil, which is then used to drive the generator to produce electricity.

\section{Wave Energy Conversion System with Pendulum System (PLTG-SB)}

The wave energy conversion system unit has a hexagon shape with three floaters connected with arms. The hexagonal-shaped platform allows as much movement (pitching) as possible because it has more surface to react with waves and winds from all directions possible, while the floater's arms act as a stabilizer to keep the platform from over slanting.

\section{Theory of Floating Structures and Motion Response}

A ponton is an example of floating structures that do not have a prime mover just like a ship would; therefore, its motion will heavily be affected by environmental forces such as waves and winds [2]. The stability is the ability of a floating structure to go back to its initial position after experiencing disturbance from internal or external factors, for example, the environmental load (Wave and wind). There are two types of stability, horizontal stability, and longitudinal stability. The horizontal stability means that the structure is experiencing a trim while the longitudinal stability means that the structure is experiencing a rolling. There are three important aspects to be considered as part of the stability, and they are the center of gravity, the center of buoyancy, and the metacentric point[11] [12].

\section{E. Six Degrees of Freedom}

A floating structure on a surface of the water will experience that six-movement that is divided into two categories, the translational that includes the surge, yaw, and sway, and the rotational motions that include the pitch, heave, and roll [3] [11].

\section{F. Response Amplitude Operator}

Response Amplitude Operator (RAO) is the function of structure response when affected by wave load towards the structure [8]. Therefore, the function can be written as the ratio between the structure respond amplitude to the wave amplitude. Structure respond amplitude can be in the form of motions, vibration, or tension. RAO is then represented in the form of the response curve. The response curve of a floating structure is divided into three different areas, the subcritical, critical, and supercritical area. The analysis of RAO graphs will surface information about the behavior of the floating structure that can be used for other analyses. [7]

\section{G. Mooring Configuration for Floating Structure}

Mooring is a set of equipment with a permanent structure that is used to make sure the structure will not get swept away by the waves [5]. The wave energy conversion system in this research needs to have as many motion responses as possible to allow the pendulums to keep moving. Thus, electricity is guaranteed to be produced [6]. Therefore, a single point mooring system is used. In this research, the mooring system will be installed on the pontoon of the wave energy conversion system to figure out the operability of the structure when moored [3] [13].

\section{H. Excursion}

The excursion is the shifting of floating structure position caused by natural loads such as wind, current, and waves that are acting upon it.

\section{Ultramarine MOSES}

Moses or Ultramarine's MOSES software is a software utilizes for offshore floating structure design optimization. It consists of numbers of simulation, the Launch, mooring, ballasting, stability, seakeeping, upending, lowering, loadout, deck installation, in-place analysis, and transportation. The type of structures that can be analyzed also varies, starting from fixed platforms, compliant towers, wind turbines, and many more [14]

\section{METHOD}

This study uses MOSES integrated simulation process to gather analytical data needed for this research.

\section{A. 3D Numerical Model of the Ponton}

The numerical modeling of the ponton for the motion analysis in MOSES is done in a two-step. The first step is to make the model in 3D solid to determine the center of gravity (CG), a moment of inertia, mass, and volume of the pontoon model. The second step is to make the 3D modeling in the surface modeler. The purpose is to obtain hydrostatic properties of the pontoon, such as the draft and zero points of the model.

The 3D model from the surface model is then exported as File.DAT or File.dat by opening the file in Moses Modeller and save it as Moses Trimesh Model to later be used in the seakeeping simulation in motion analysis software. Generate Trimesh command can be found in the Trimesh option of Surfaces [15]. The hydrostatic data of the model can be determined by going to the Calculate Hydrostatic option in the data tab. 3D numerical modeling can be seen in Figure. 1.

\section{B. Simulation of Motion Response}

Simulation in motion response software is done to gather data of the Response Amplitude Operator (RAO) of the ponton. The simulation is conducted by coding in Moses Editor. The steps are as the following: 
International Journal of Marine Engineering Innovation and Research, Vol. 5(2), Jun. 2020. 68-80 (pISSN: 2541-5972, eISSN: 2548-1479)

1. Input of Parameters

The input parameters needed for the simulation are divided into few categories, the hydrostatic input and environmental parameters input. The hydrostatic input includes the wave spectrum, draft, center of gravity, and radius of Gyration of the pontoon, while the environmental parameter input includes sea current, wind speed, water depth, and wave height significant. There should be at least one spectrum input; in this research, the JONSWAP spectrum is used. The speed of the vessel is 0 $\mathrm{m} / \mathrm{s}$ because the ponton is in a free-floating position.
The environmental loads, such as water depth, speed, and direction of the wind, and wave properties must be according to the existing data from the location at which the ponton is placed. The hydrostatic input should also match the data derived from the process of $3 \mathrm{D}$ modeling. The input parameter for motion analysis can be shown seen in Table 1.

TABLE 1.

PARAMETER INPUT MOTION ANALYSIS

\begin{tabular}{clcc}
\multicolumn{5}{c}{ PARAMETER INPUT MOTION ANALYSIS } \\
\hline No. & \multicolumn{1}{c}{ Input } & Value & Units \\
\hline 1. & Wave Spectrum & JONSWAP & - \\
2. & Wave Height Significant & 2,364 & Meters \\
3. & Sea Current & 0,49 & $\mathrm{~m} / \mathrm{s}$ \\
4. & Period & 7,74 & Second \\
5. & Water Depth & 25 & $\mathrm{~meters}$ \\
6. & Wind Speed & 16 & $\mathrm{~m} / \mathrm{s}$ \\
7. & Vessel Draft & 0,837 & Meters \\
8. & Gamma & 1 & Meter \\
9. & Wave Heading & $0-120$ & Degrees \\
\hline
\end{tabular}
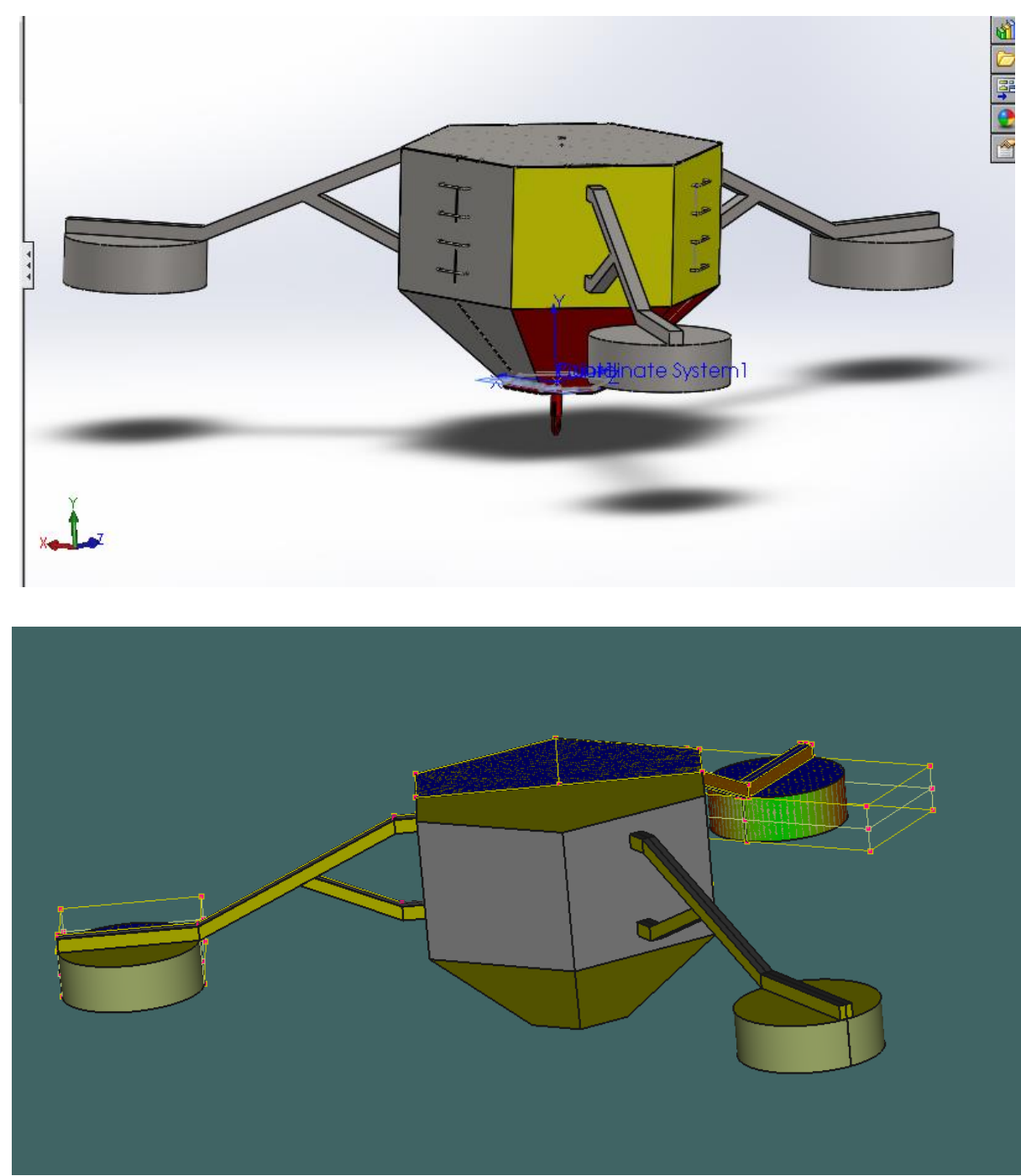

Figure. 1. Numerical modelling in Solidwork and Maxsurf. 


\section{Mooring System Simulation}

There are three types of simulation, the Modal Analysis, Static Analysis, and Dynamic Analysis. Dynamic Analysis is used in this research because it carries out a time-domain simulation of the response of the system to waves, current, and other input parameters intended by the user. The mooring system that is used in this research is the Single Point Mooring system. The data needed are the calculated mooring line length, mooring line specifications, the same environmental parameters as used in Moses, and the data output derived from the motion simulation in the panel method [16].

The data of tension distribution of the mooring line, excursion, and motion of the model after moored is then analyzed to figure out which type of mooring line is the most suitable based on its properties such as the material,

TABLE 2.

\begin{tabular}{lcccc}
\multicolumn{5}{c}{ THE PRINCIPAL DIMENSION OF PONTOON } \\
\hline Length $(\mathrm{m})$ & Draft $(\mathrm{m})$ & $\begin{array}{c}\text { Height } \\
(\mathrm{m})\end{array}$ & Radius $(\mathrm{m})$ \\
\hline Pontoon & 3,5 & 0,837 & 2,5 & 1,73 \\
Floaters & 2,36 & - & 0,15 & 0,75 \\
\hline
\end{tabular}

\section{B. 3D Numerical Modelling of Pontoon}

There are three variations of design, and design Variation 1 is the initial design, design Variation 2 is the pontoon designed with reduced floater arms, variation 3 is the design of pontoon without floaters. Based on the mass maximum tension, mass per meter, and tensile strength or any other data needed for the analysis. The data is derived from the Select Results option.

\section{RESULTS AND DISCUSSION}

After conducting the research based on the methodology, the analysis based on the results has been carried out.

\section{A. Main Dimension of Pontoon}

The principal dimension of the pontoon platform and the floaters derived from 2D drawings are shown in Table 2.

TABLE 3.

PONTOON VARIATION 1 INITIAL DESIGN

\begin{tabular}{cccc}
\hline Axis & $\begin{array}{c}\text { Moment of inertia } \\
\left(\text { Ton. } \text { m }^{2}\right.\end{array}$ & Center of Gravity & $\begin{array}{c}\text { The radius of } \\
\text { Gyration (meter) }\end{array}$ \\
\hline $\mathrm{X}$ & 95,246 & 0 & 3,283 \\
$\mathrm{Y}$ & 168,132 & 1.05 & 4,362 \\
$\mathrm{Z}$ & 95,192 & 0 & 3,282 \\
\hline
\end{tabular}

TABLE 4

the value of the center of mass $x, y$, and $z$ coordinates, the radius of Gyration, a moment of inertia $\mathrm{I}_{\mathrm{xx}}, \mathrm{I}_{\mathrm{yy}}$, and $\mathrm{I}_{\mathrm{zz}}$ are as written in Tables below.

PONTOON VARIATION 2 REDUCED DistanCE FLOATER

\begin{tabular}{cccc}
\hline Axis & $\begin{array}{c}\text { Moment of inertia } \\
\left.(\text { Ton. })^{2}\right)\end{array}$ & $\begin{array}{c}\text { Center of } \\
\text { Gravity }\end{array}$ & $\begin{array}{c}\text { The radius of } \\
\text { Gyration (meter) }\end{array}$ \\
\hline $\mathrm{X}$ & 71,369 & 0 & 2,847 \\
$\mathrm{Y}$ & 120,476 & 1,05 & 3,699 \\
$\mathrm{Z}$ & 71,316 & 0 & 2,847 \\
\hline
\end{tabular}

TABLE 5 . PONTOON VARIATION 3 WITHOUT FLOATER

\begin{tabular}{cccc}
\hline Axis & $\begin{array}{c}\text { Moment of inertia } \\
\left(\text { Ton. }{ }^{2}\right)\end{array}$ & Center of Gravity & $\begin{array}{c}\text { Radius of Gyration } \\
\text { (meter) }\end{array}$ \\
\hline $\mathrm{X}$ & 8,917 & 0 & 2,034 \\
$\mathrm{Y}$ & 3,434 & 1,57 & 1,262 \\
$\mathrm{Z}$ & 8,765 & 0 & 2,017 \\
\hline
\end{tabular}

\section{Modeling in Ultramarine Moses}

The modeling in Moses is done by opening a design file .msd of the 3D model from Maxsurf Advanced with a fixed hydrostatic data. The model is then proceeded to be set for seakeeping simulation to generate Response Amplitude Operation (RAO) in a free-floating condition by trimeshing it, then exporting it into a.DAT file. The results of trimeshing are as seen in the figure below. 
International Journal of Marine Engineering Innovation and Research, Vol. 5(2), Jun. 2020. 68-80 (pISSN: 2541-5972, eISSN: 2548-1479)

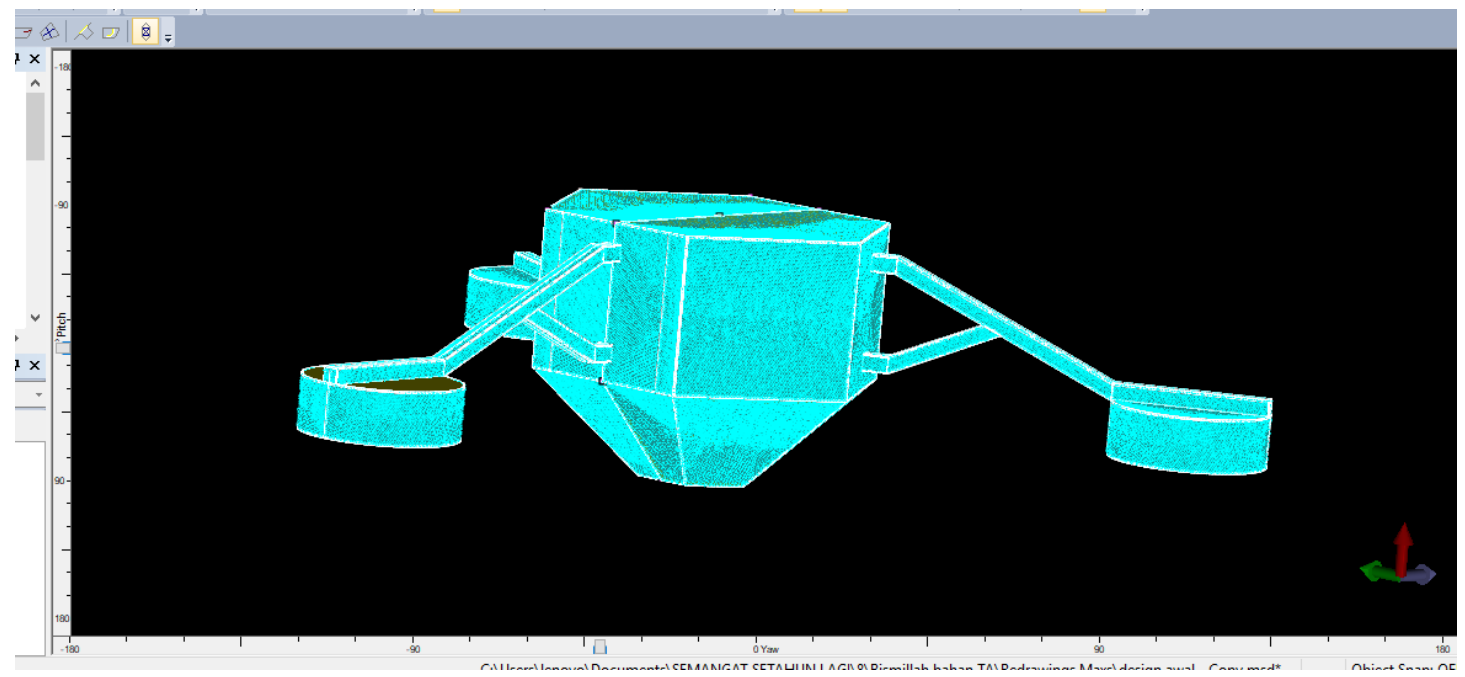

Figure. 2. Mesh of model in Moses.

\section{Motion Response Analysis}

In this analysis, the RAO data shows the characteristics of the initially designed pontoon motion before the mooring system is installed; hence, the free-floating state. The RAO data are given in a Wave Frequency ( $\mathrm{rad} / \mathrm{s})$ versus RAO $(\mathrm{m} / \mathrm{m})$ and RAO $(\mathrm{deg} / \mathrm{m})$ for both translational and rotational motion consecutively. The analysis of RAO graphs for each variation is as given in the following.

\section{E. Motion Response Analysis of Variation 2}

The motion analysis for pontoon without floaters is given for surge, sway, heave, roll, pitch, and yaw. These analyses are as shown in the following subchapters. a. RAO Analysis for Surge Motion

Figure. 3 shows that the Surge RAO value data for all load headings from $0^{\circ}$ until $120^{\circ}$ have the same pattern. Each heading has the highest RAO when the frequency is at around 1,57 Rad/s, and then the RAO keeps declining. The highest initial RAO value is $1,194 \mathrm{~m} / \mathrm{m}$ frequency $1,25 \mathrm{Rad} / \mathrm{s}$ due to load heading from $90^{\circ}$, followed by 30 ${ }^{\circ}, 60^{\circ}, 0^{\circ}$, and $120^{\circ}$.

The highest surge RAOs occurs at frequency 1,57 $\mathrm{Rad} / \mathrm{s}$ with the highest RAO is $2,596 \mathrm{~m} / \mathrm{m}$ due to load from heading $0^{\circ}$. it can be concluded that load coming from $0^{\circ}$ heading has the biggest impact on the pontoon, this is accordant to the characteristic of surge motion being heavily impacted by the wave at bow and stern, which in this analysis is the load heading of $0^{\circ}$

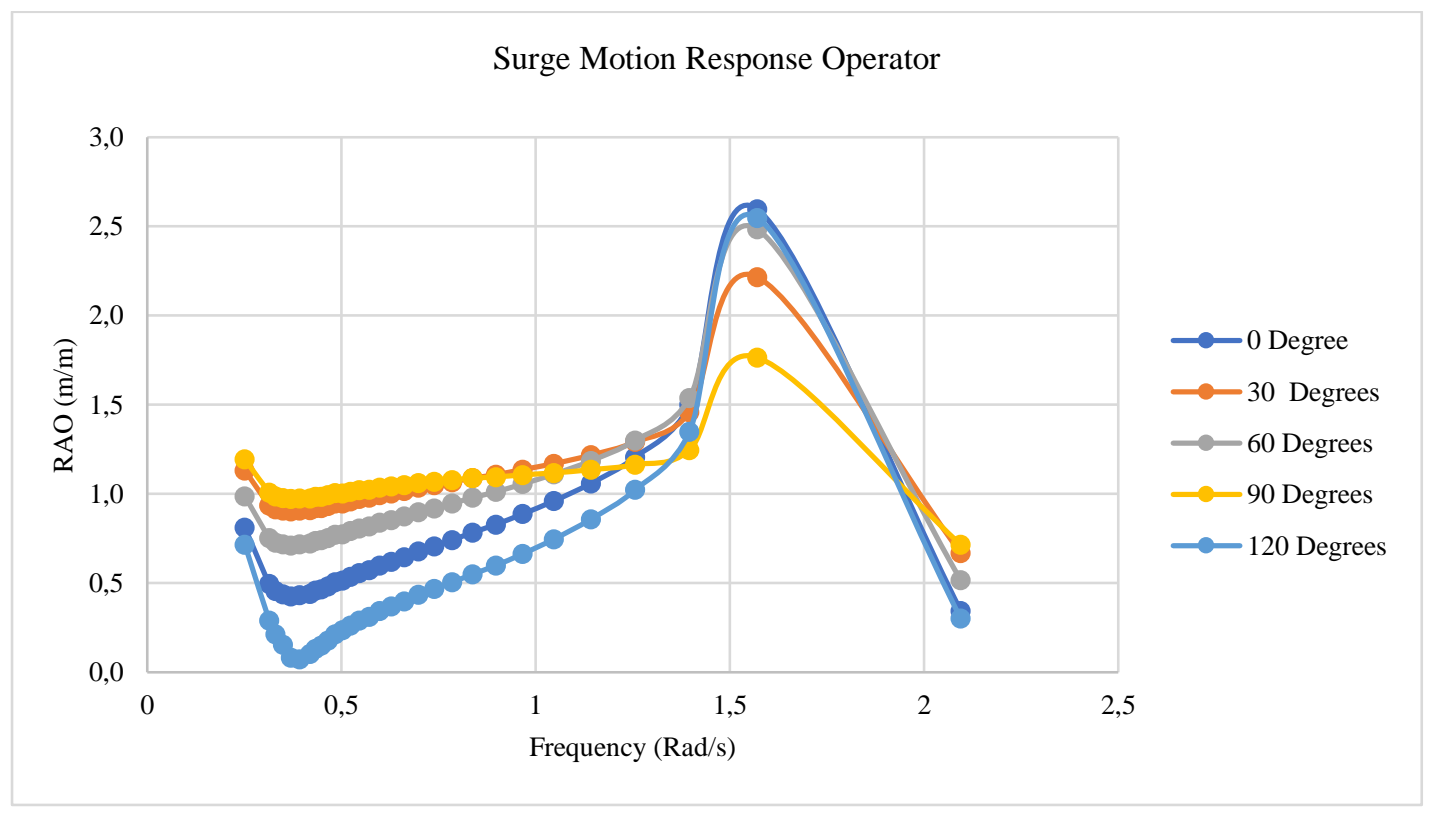

Figure. 3. Surge RAO of variation 1. 
b. RAO Analysis for Sway Motion

The data in Figure. 4 shows that as the frequency increases, the sway motion RAO values in all load headings are steadily declining. All RAO start to decline around frequency $0,4 \mathrm{Rad} / \mathrm{s}$ after the peak, and then it stays stable. The highest value of sway motion RAO is due to load from $90^{\circ}$ heading starting at $2 \mathrm{~m} / \mathrm{m}$ frequency $0,25 \mathrm{rad} / \mathrm{s}$, followed by RAO in load heading $30^{\circ}, 60^{\circ}$, $120^{\circ}$, and $0^{\circ}$ at $1,88 \mathrm{~m} / \mathrm{m}, 1,58 \mathrm{~m} / \mathrm{m}, 1,18 \mathrm{~m} / \mathrm{m}$, and 0,04 $\mathrm{m} / \mathrm{m}$ consecutively.
Based on the analysis, it is still accordant to the characteristic. Sway motion will most likely be occurring when the load is coming horizontally towards the pontoon, which is the highest when the load is coming from $90^{\circ}$ heading, followed by $120^{\circ}$ and $60^{\circ}$, and then the lowest at $30^{\circ}$. Sway motion will not likely to occur when the load is coming towards the bow or stern, which is proved by values at $0^{\circ}$ that are close to zero.

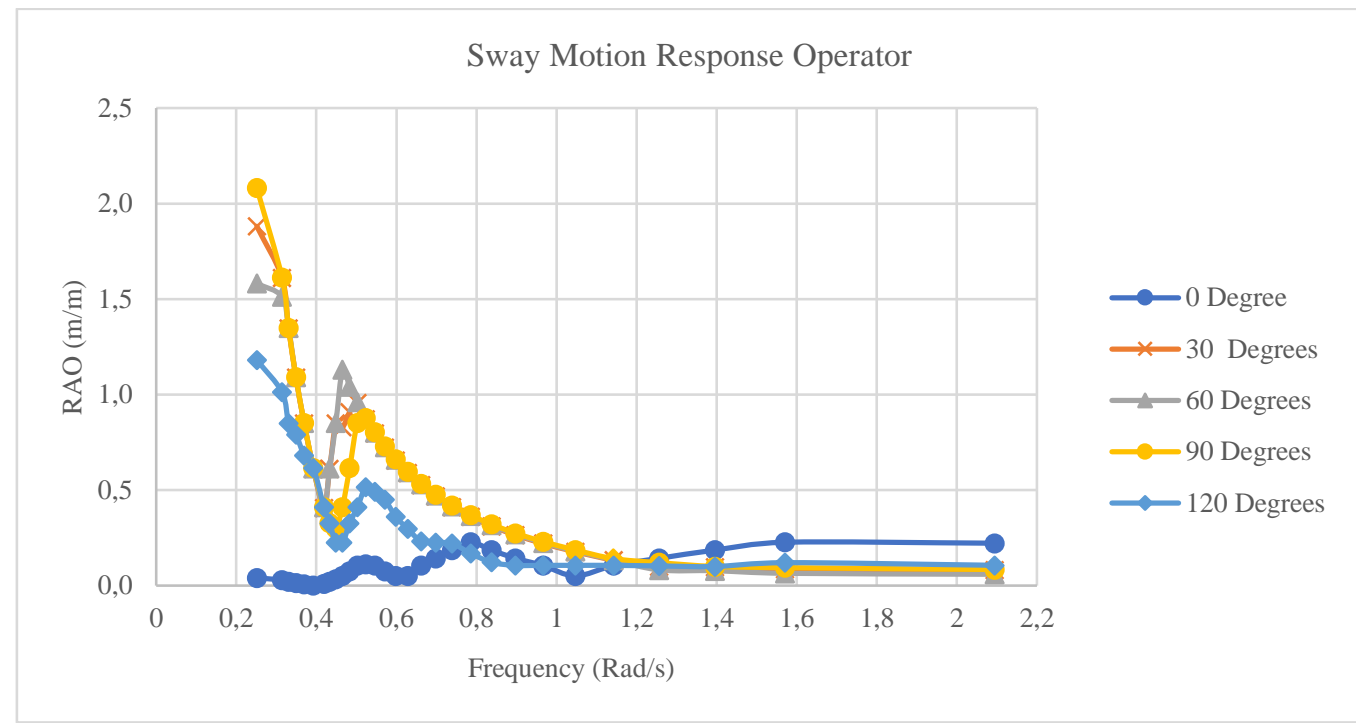

Figure. 4. Sway RAO of variation 1.

c. RAO Analysis for Heave Motion

The data in Figure. 5 shows that the heave RAO data have an identical pattern. The graphs are steadily decreasing, although there are a few raises, the values are expected to also decline towards zero at a certain higher frequency. This is likely due to the the symmetrical shape of the pontoon hull that makes it easier for the pontoon to stabilize.

The highest values of heave RAO are reached in load heading $90^{\circ}$ at $1,6 \mathrm{~m} / \mathrm{m}$ frequency $0,24 \mathrm{rad} / \mathrm{s}$. The heave RAO is highly impacted by load coming from $90^{\circ}$ heading, followed by $120^{\circ}, 30^{\circ}, 0^{\circ}$, and then $60^{\circ}$. The values of heave RAOs for Variation 2 are higher compared to Variation 1 is likely caused by its lower mass.

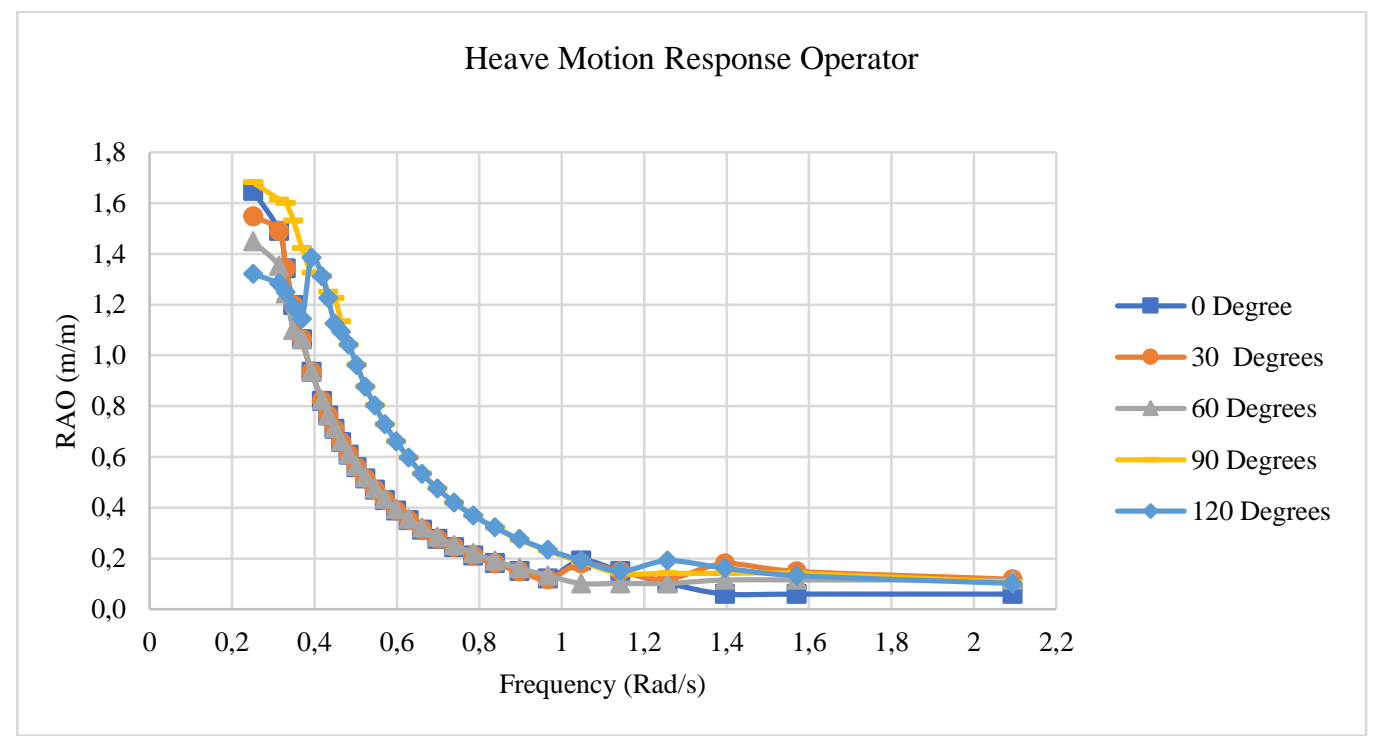

Figure. 5. Heave RAO of variation 1. 
d. RAO Analysis for Pitch Motion

Figure. 6 shows that pitch RAO keeps on inclining as the frequency increases. The highest pitch RAO occurred is at $18,17 \mathrm{deg} / \mathrm{m}$ from load heading $0^{\circ}$, then the second-highest at $16 \mathrm{deg} / \mathrm{m}$ from load heading $120^{\circ}$, followed by RAO at $12,1 \mathrm{deg} / \mathrm{m}$ from load heading $90^{\circ}$, then at $10,04 \mathrm{deg} / \mathrm{m}$ from load heading $60^{\circ}$, and the least high being at $8,5 \mathrm{deg} / \mathrm{m}$ from load heading $30^{\circ}$.

This set of data shows that the pitch RAO for the pontoon is heavily affected by loads coming from $0^{\circ}$ heading. This is accordant to the characteristic of pitch motion because the pitch is the rotational motion on the $\mathrm{z}$ axis of the floating body, which makes it vulnerable to loads coming towards the bow and stern of the floating body.

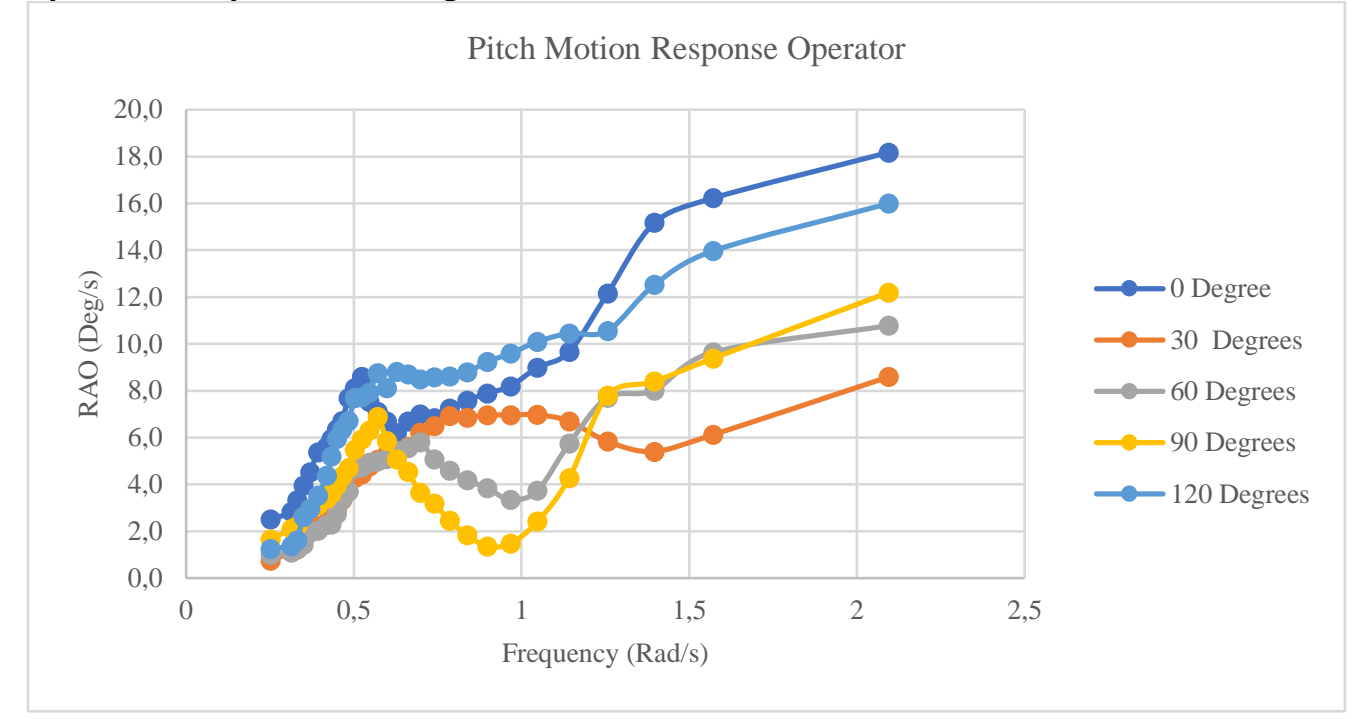

Figure. 6. Pitch RAO of variation 1.

e. RAO Analysis for Roll Motion

The data in Figure. 7 shows an identical parabolic pattern for every load heading, except for $0^{\circ}$ heading, because roll motion is unlikely to be affected by loads coming towards the bow and stern of the pontoon, which in this analysis is the $0^{\circ}$ heading. This is proofed by the zero RAO values from $0^{\circ}$ heading in the graph. The highest value of roll RAO is at $16,9 \mathrm{deg} / \mathrm{m}$ frequency 0,66 $\mathrm{rad} / \mathrm{s}$ due to load from $90^{\circ}$ heading, followed by 14,92 $\mathrm{rad} / \mathrm{m}$ frequency $0,7 \mathrm{rad} / \mathrm{s}$ from heading $60^{\circ}$, then at 14,4 $\mathrm{rad} / \mathrm{m}$ frequency $0,66 \mathrm{rad} / \mathrm{s}$ from $120^{\circ}$ heading, and lastly at $10,9 \mathrm{rad} / \mathrm{m}$ frequency $0,78 \mathrm{rad} / \mathrm{s}$ from $30^{\circ}$ heading, load coming from $90^{\circ}$ heading being the most affecting.

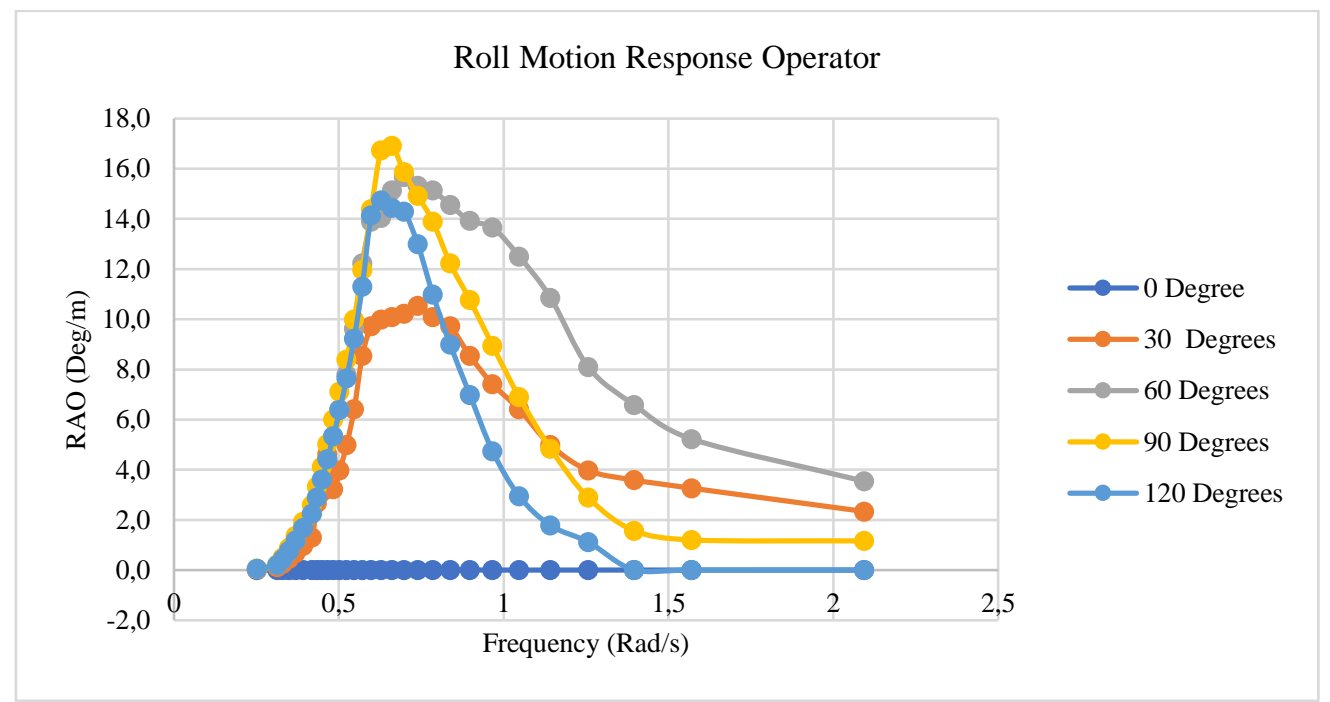

Figure. 7 Roll RAO of variation 1.

\section{f. RAO Analysis for Yaw Motion}

The data in Figure. 8 shows that yaw RAO is mostly affected by loads coming from $120^{\circ}$ heading. The yaw RAO value data set for heading $120^{\circ}$ is the highest compared to the other headings. Meanwhile, the difference in yaw RAO value data set for heading $0^{\circ}$ is also very drastic because all of the values are very close to zero.

The highest yaw RAO is at $37,2 \mathrm{deg} / \mathrm{m}$ frequency 0,7 $\mathrm{deg} / \mathrm{m}$ due to loads from $120^{\circ}$ heading, the second highest 
is at $32,3 \mathrm{deg} / \mathrm{m}$ frequency $0,74 \mathrm{deg} / \mathrm{s}$ due to load coming from $30^{\circ}$ heading, followed by $26,8 \mathrm{deg} / \mathrm{m}$ frequency 0,7 $\mathrm{deg} / \mathrm{s}$ due to load coming from $60^{\circ}$ heading, and the lowest at $14,9 \mathrm{deg} / \mathrm{m}$ frequency $0,6 \mathrm{deg} / \mathrm{s}$ due to load coming from $30^{\circ}$ heading. It can be concluded that the yaw RAO of the pontoon is highly affected by loads coming from $90^{\circ}$ heading and that the load from $0^{\circ}$ heading does not have a significant effect on the yaw RAO.

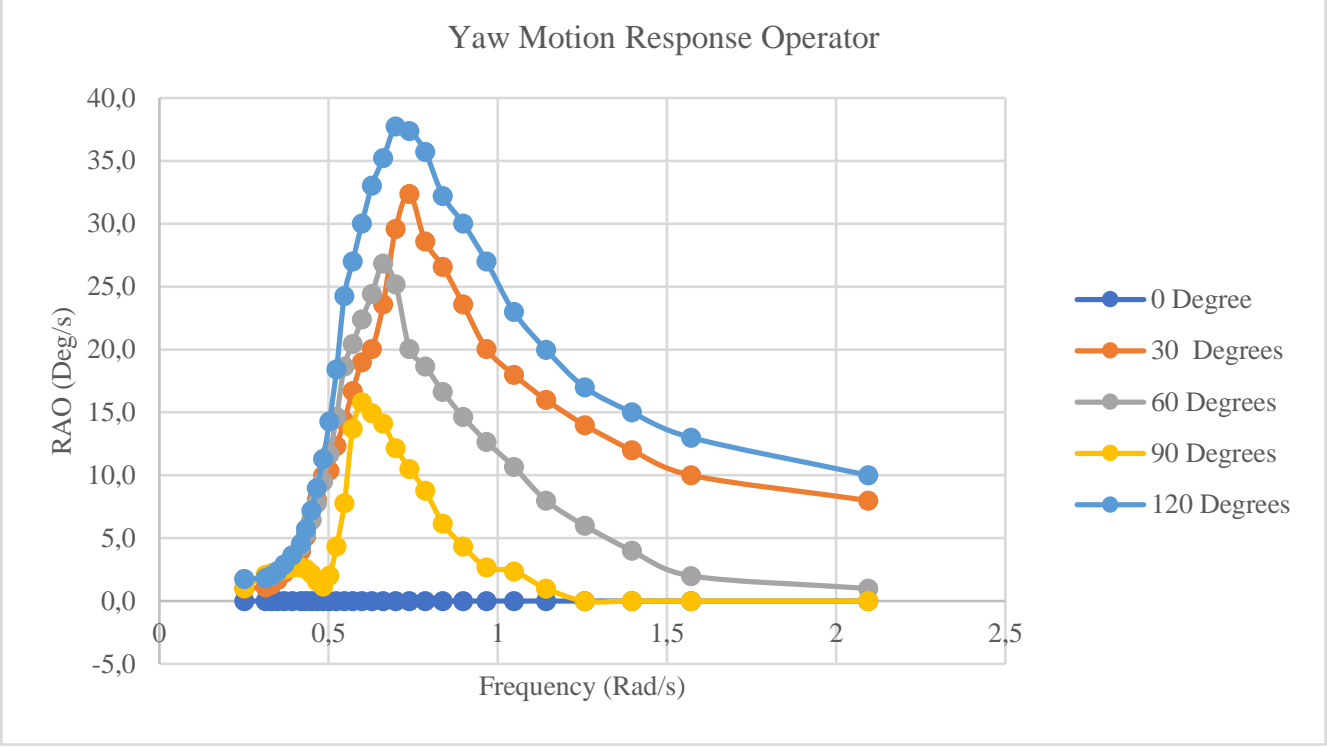

Figure. 8 Yaw RAO of variation 1.

\section{F. Motion Response Analysis of Variation 3}

The motion analysis for pontoon with shortened floater arms is given for surge, sway, heave, roll, pitch, and yaw. These analyses are as shown in the following subchapters.

Variation 3 is hexagonal pontoon without floater a. RAO Analysis for Surge Motion.

The data in Figure. 9 below shows that the Surge RAO value data for all load headings from $0^{\circ}$ until $120^{\circ}$ have an identical pattern. The highest RAO value is 1,8 $\mathrm{m} / \mathrm{m}$ frequency $1,85 \mathrm{Rad} / \mathrm{s}$ due to load heading from 0 ${ }^{\circ}$, followed by $120^{\circ}, 30^{\circ}, 90^{\circ}$, and $60^{\circ}$. It can be concluded that load coming from $0^{\circ}$ heading has the biggest impact on the pontoon, this is accordant to the characteristic of surge motion being heavily impacted by the wave at bow and stern.

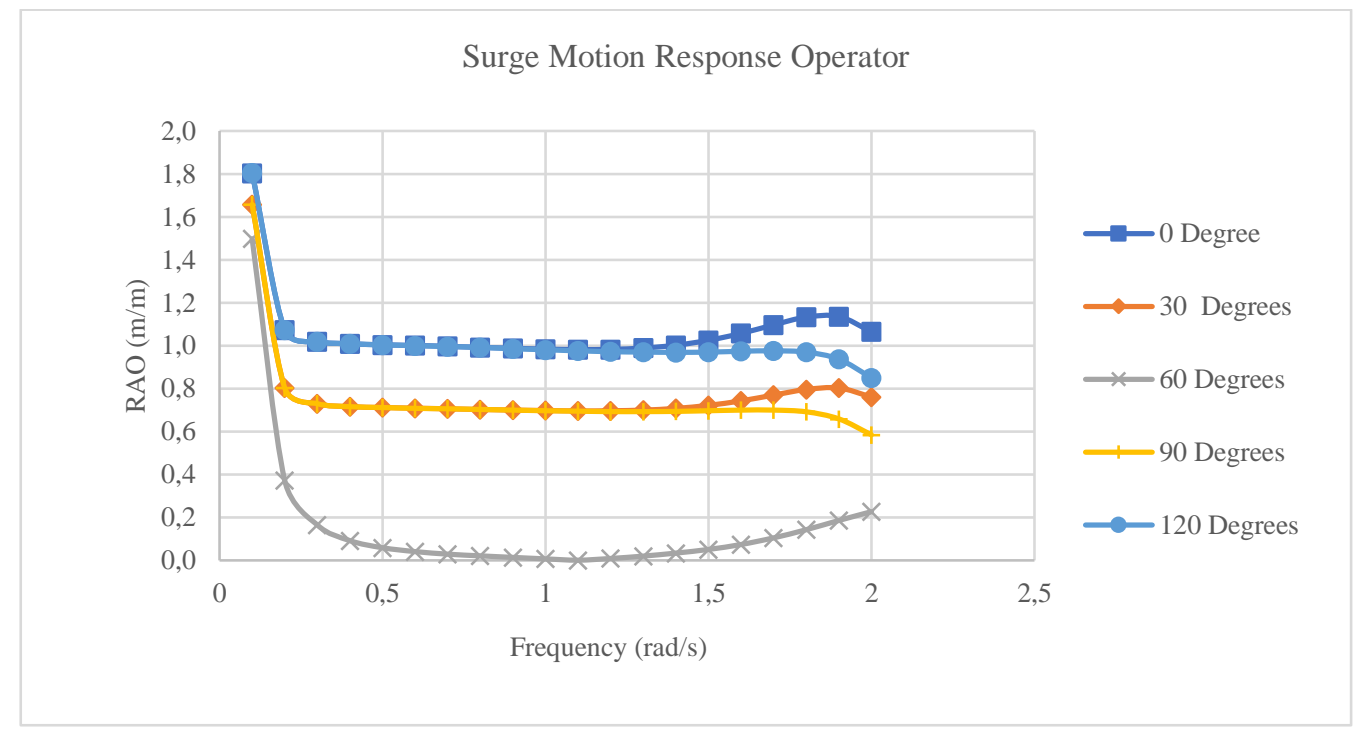

Figure. 9. Surge RAO of variation 1.

\section{J. RAO Analysis for Sway Motion}

The data in Figure. 10 shows that as the frequency increases, the sway motion RAO values due to all load headings are steadily decreasing, except for load at $120^{\circ}$ heading that stays at $0 \mathrm{~m} / \mathrm{m}$. The highest set of sway motion RAO value is due to load from $60^{\circ}$ heading starting at $0,99 \mathrm{~m} / \mathrm{m}$ frequency $0,1 \mathrm{rad} / \mathrm{s}$; the highest RAO is due to load from heading $60^{\circ}$ at 1,8 $\mathrm{m} / \mathrm{m}$ frequency $1,005 \mathrm{rad} / \mathrm{s}$. Sway motion is not likely to occur when the load is coming towards the bow or stern, which is proved by the zero values for heading at $0^{\circ}$. Sway motion will most likely be occurring when the 
International Journal of Marine Engineering Innovation and Research, Vol. 5(2), Jun. 2020. 68-80 (pISSN: 2541-5972, eISSN: 2548-1479)

load is coming horizontally towards the pontoon, heading, followed by $90^{\circ}$ and $30^{\circ}$, and then the lowest which is the highest when the load is coming from $60^{\circ}$ at $120^{\circ}$ and $0^{\circ}$.

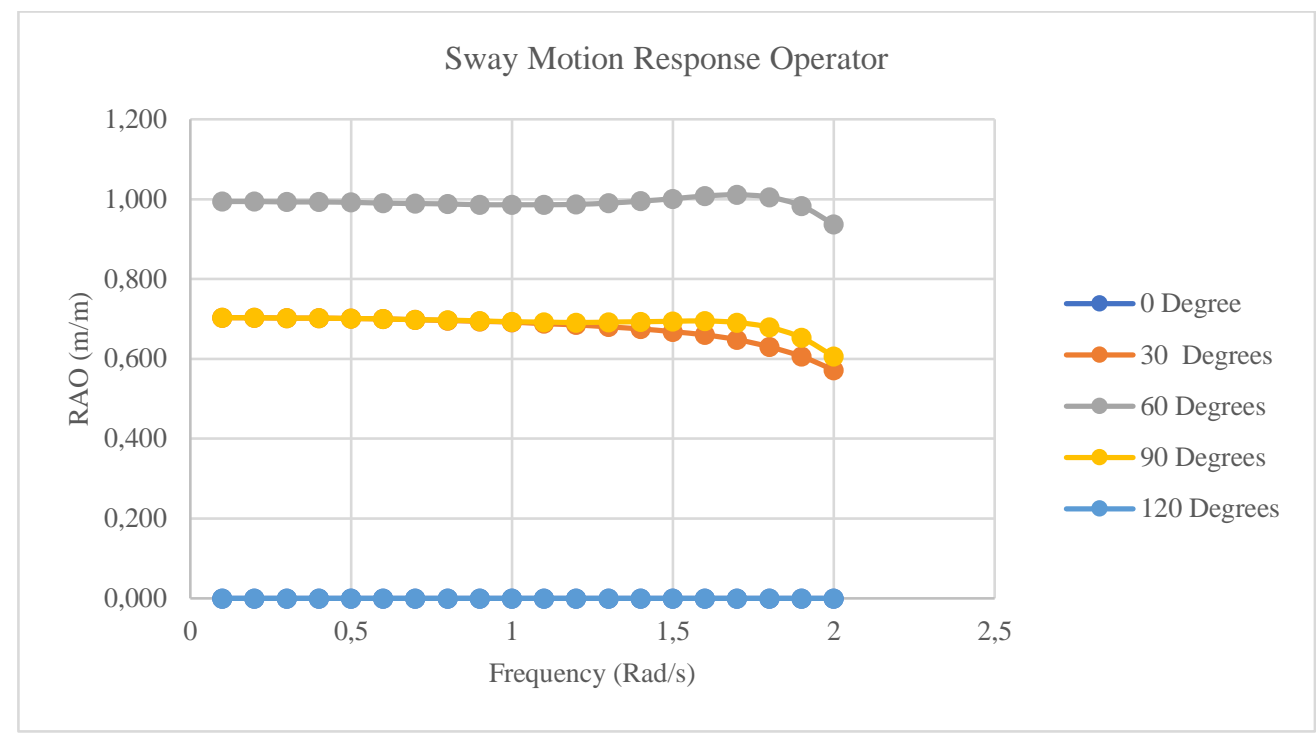

Figure. 10. Sway RAO of variation 1.

$K$. RAO Analysis for Heave Motion

The data in Figure. 11 shows that the heave RAO data have an identical pattern. The graphs are steadily decreasing. This is likely due to the symmetrical shape of the pontoon hull that makes it easier for the pontoon to stabilize. However, the values began to incline and decline at the same time after frequency $1,6 \mathrm{Rad} / \mathrm{s}$.
The highest values of heave RAO is reached in load heading $0^{\circ}$ at $1,07 \mathrm{~m} / \mathrm{m}$ frequency $24 \mathrm{rad} / \mathrm{s}$. The heave RAO is highly impacted by load coming from $120^{\circ}$ heading, followed by $90^{\circ}, 60^{\circ}, 30^{\circ}$, and then $0^{\circ}$. The values of heave RAOs for Variation 3 are higher compared to Variation 1, and 2 is likely due to lower mass since it does not have any floaters and floater arms.

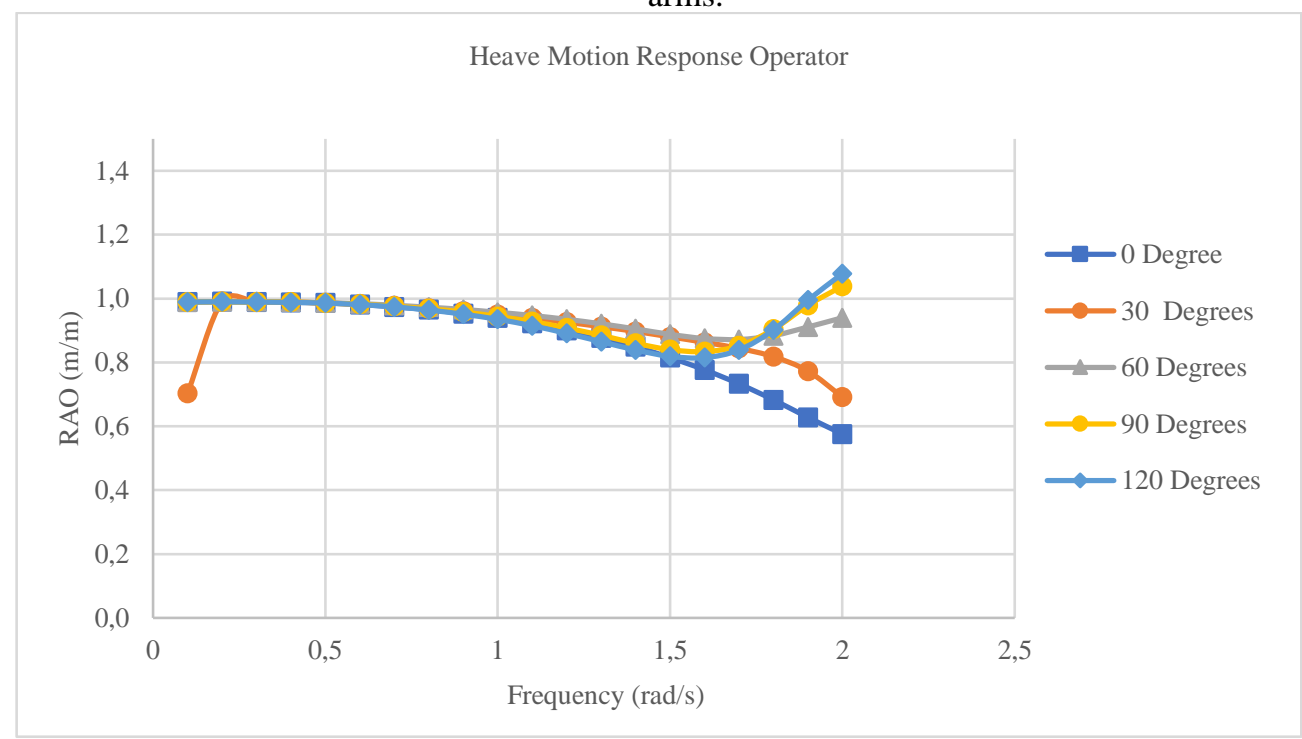

Figure. 11. Heave RAO of variation 3.

\section{RAO Analysis for Pitch Motion}

Figure. 12 shows that pitch RAO keeps on inclining as the frequency increases. The highest pitch RAO occurred is at $20,86 \mathrm{deg} / \mathrm{m}$ from load heading $120^{\circ}$, then the second-highest at 19,13 deg/m from load heading $0^{\circ}$, followed by RAO at $13,8 \mathrm{deg} / \mathrm{m}$ from load heading $30^{\circ}$, then at $12 \mathrm{deg} / \mathrm{m}$ from load heading $90^{\circ}$, and the least high being at $12,3 \mathrm{deg} / \mathrm{m}$ from load heading $60^{\circ}$. This set of data shows that the pitch RAO for the pontoon is heavily affected by loads coming from $120^{\circ}$ and $0^{\circ}$ heading. This is accordant to the characteristic of pitch motion because the pitch is the rotational motion on the $\mathrm{z}$-axis of the floating body, 
International Journal of Marine Engineering Innovation and Research, Vol. 5(2), Jun. 2020. 68-80

(pISSN: 2541-5972, eISSN: 2548-1479)

which makes it vulnerable to loads coming towards the bow and stern of the floating body.

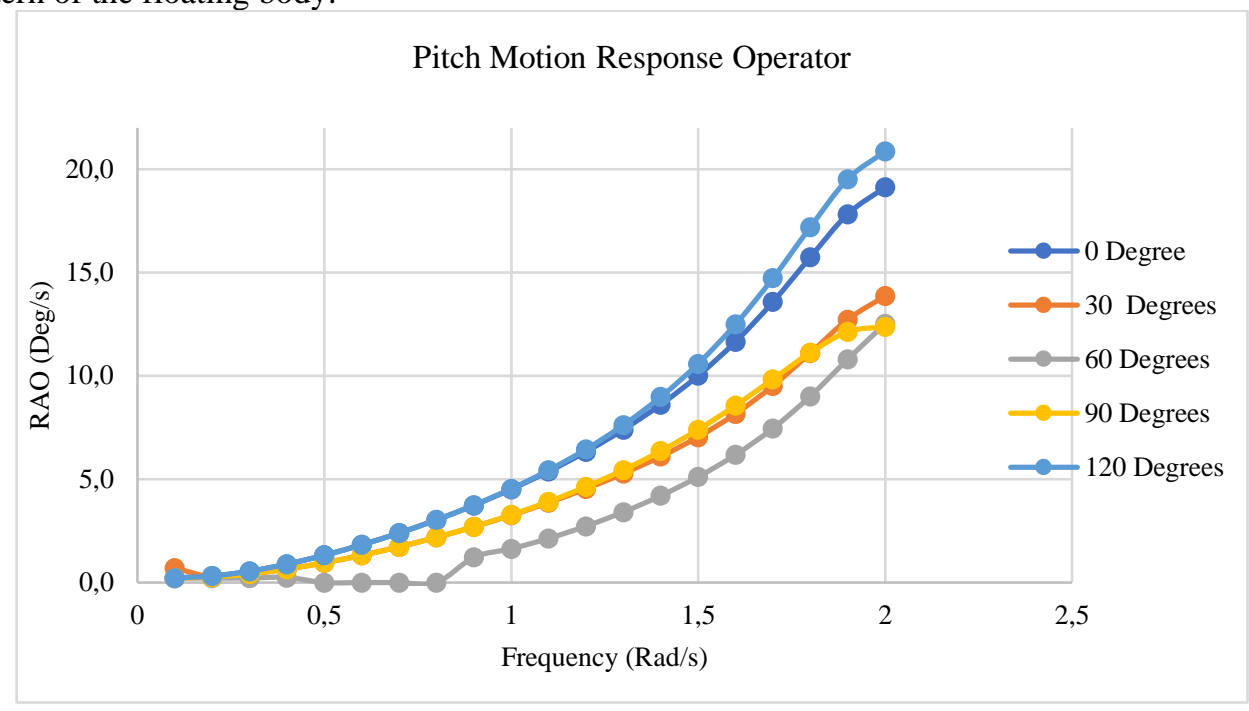

Figure. 12. Pitch RAO of variation 3.

M. RAO Analysis for Roll Motion

The data in Figure. 13 shows an identical exponential pattern for every load heading, except for $0^{\circ}$ heading because it is unlikely going to be affected by loads coming towards the bow and stern of the pontoon, which in this analysis is the $0^{\circ}$ heading since it is horizontally rotational motion. This is proofed by the zero RAO values from the load coming from $0^{\circ}$ heading in the Figure. The highest value of roll RAO is at $13,1 \mathrm{deg} / \mathrm{m}$ frequency $2 \mathrm{rad} / \mathrm{s}$ due to load from $60^{\circ}$ heading, followed by $11,2 \mathrm{rad} / \mathrm{m}$ frequency $2 \mathrm{rad} / \mathrm{s}$ from heading $90^{\circ}$, then at $8,04 \mathrm{rad} / \mathrm{m}$ frequency $2 \mathrm{rad} / \mathrm{s}$ from $30^{\circ}$ heading, and lastly at $1,9 \mathrm{rad} / \mathrm{m}$ frequency 1,9 $\mathrm{rad} / \mathrm{s}$ from $1200^{\circ}$ heading, load coming from $60^{\circ}$ heading is the most effecting load to model Variation 1.

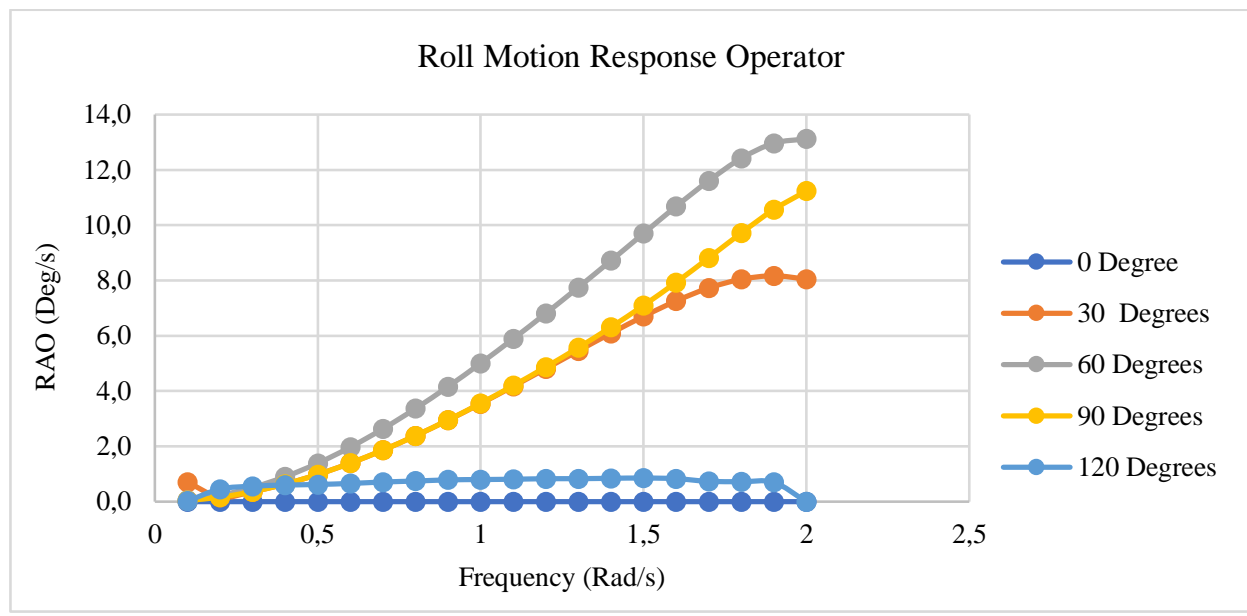

Figure. 13. Roll RAO of variation 3 .

N. RAO Analysis for Yaw Motion

The data in Figure. 14 shows that yaw RAO for this model variation is mostly affected by loads coming from $30^{\circ}$ heading. The yaw RAO value data set for heading $30^{\circ}$ is the highest compared to the other headings. Meanwhile, the difference in yaw RAO value data set for heading $0^{\circ}$ is also very drastic because all of the values are very close to zero. The highest yaw RAO is at $0,891 \mathrm{deg} / \mathrm{m}$ frequency $2 \mathrm{deg} / \mathrm{m}$ due to loads from $30^{\circ}$ heading, the second highest is also at 0,81 $\mathrm{deg} / \mathrm{m}$ frequency $2 \mathrm{deg} / \mathrm{s}$ due to load coming from $90^{\circ}$ heading, followed by $0,37 \mathrm{deg} / \mathrm{m}$ frequency $2 \mathrm{deg} / \mathrm{s}$ due to load coming from $60^{\circ}$ heading, and the lowest at 0,2 $\mathrm{deg} / \mathrm{m}$ also at frequency $2 \mathrm{deg} / \mathrm{s}$ due to load coming from $0^{\circ}$ heading. It can be concluded that the yaw RAO of the pontoon is highly affected by loads coming from $30^{\circ}$ heading and that the load from $120^{\circ}$ heading does not have a significant effect on the yaw RAO. 
International Journal of Marine Engineering Innovation and Research, Vol. 5(2), Jun. 2020. 68-80 (pISSN: 2541-5972, eISSN: 2548-1479)

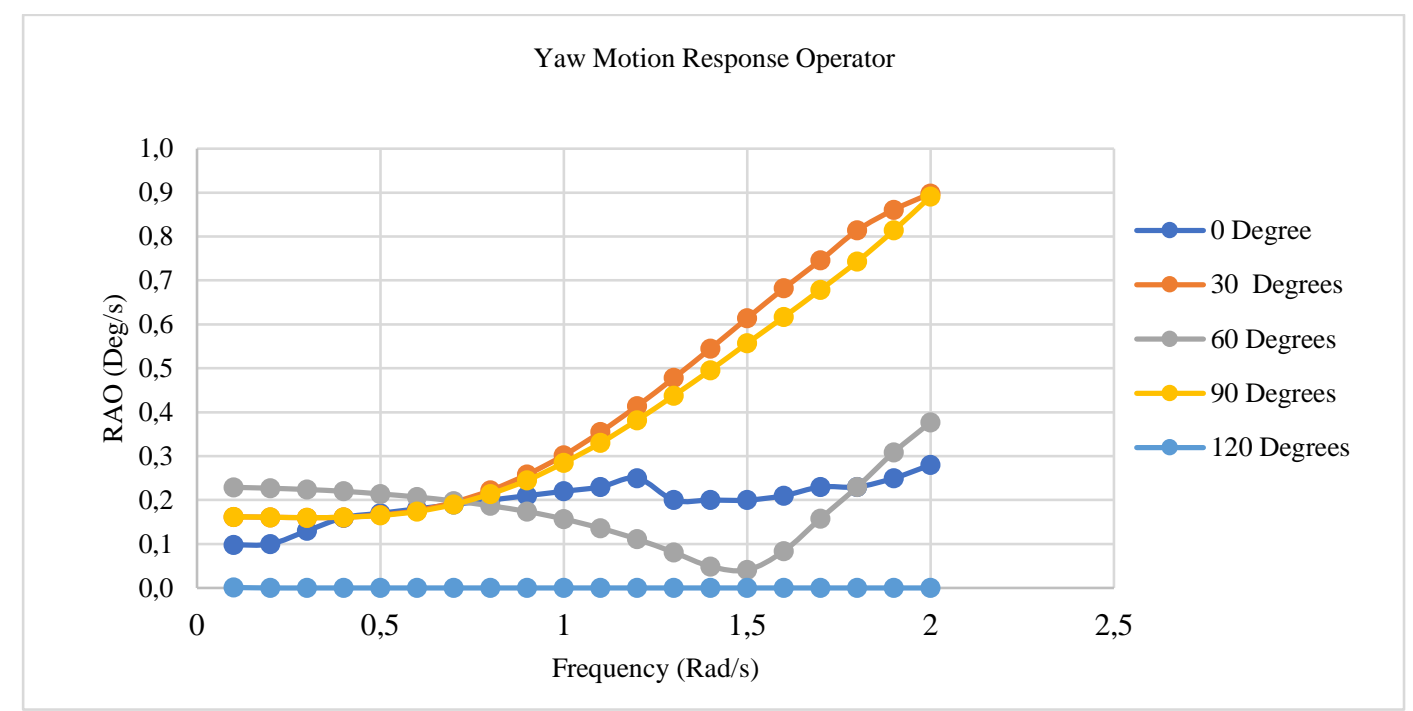

Figure. 14. Sway RAO of variation 3 .

\section{F. Mooring System Configuration}

Mooring system analysis requires two objects, the pontoon (vessel) and the mooring line. The pontoon is redrawn while the mooring line is selected and placed according to a single point mooring configuration

\section{G. Pontoon Excursion Analysis}

The excursion of the pontoon in $\mathrm{x}$-axes and $\mathrm{y}$ axes is derived from the mooring simulation. The simulation is conducted for 10800 seconds (operation should be. The mooring line is attached at the bottom of the pontoon at point coordinate $(x, y, z)=(0,0,0)$. The depth of water is 22,9 meters, with a length of mooring line 29,4 meters.

time) for all load heading $0^{\circ}, 30^{\circ}, 60^{\circ}, 90^{\circ}, 120^{\circ}$. The result of the simulation is shown in Table 6 below.

TABLE 1

EXCURSION ANALYSIS OF PONTOON WITH A MOORING SYSTEM.

\begin{tabular}{ccc}
\hline Heading & \multicolumn{2}{c}{ Maximum Excursion Along Axes (meters) } \\
\cline { 2 - 3 } (Degree) & $\mathrm{x}$ & $\mathrm{y}$ \\
\hline 0 & 2,9 & 5,1 \\
30 & 1 & 2,5 \\
60 & 1 & 2,52 \\
90 & 2,67 & 2,75 \\
120 & 1,5 & 2,5 \\
\hline
\end{tabular}

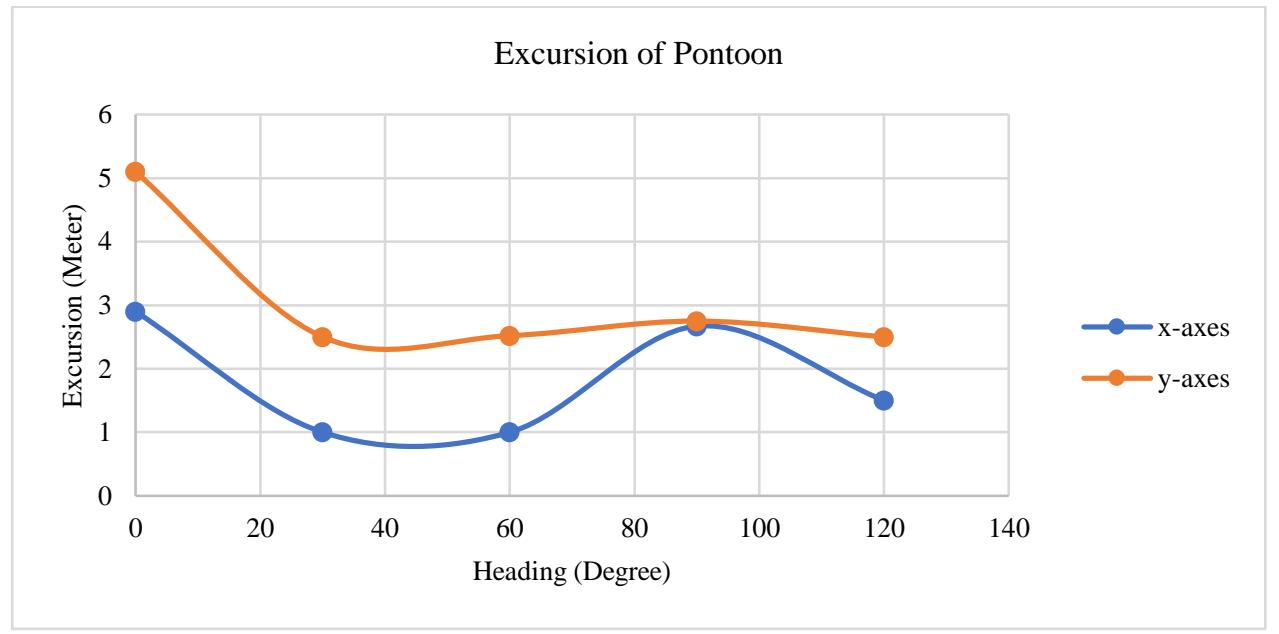

Figure. 15. Excursion along the $\mathrm{X}$ and $\mathrm{Y}$ axis of pontoon with mooring system. 
Based on data in Table 6, the comparison of maximum excursion of the pontoon after the mooring system is installed on the X and Y-axis in Figure. 15 is analyzed. The furthest excursion occurred when the load is coming from $0^{\circ}$ heading at 5,1 meters along $\mathrm{X}$ axis. The shortest excursion occurred when a load is coming from $120^{\circ}$ heading at 1,5 meters along Y-axis.

\section{H. Pontoon Motion Analysis}

The pontoon motion analysis of the pontoon in $\mathrm{x}$ axes and y-axes derived from the mooring simulation. The simulation is conducted for 10800 seconds (operation time) for all load heading $0^{\circ}, 30^{\circ}, 60^{\circ}, 90^{\circ}$, $120^{\circ}$. The result of the simulation is as shown in Table 7.

TABLE 2.

MOTION ANALYSIS OF PONTOON WITH A MOORING SYSTEM.

\begin{tabular}{ccc}
\hline $\begin{array}{c}\text { Heading } \\
\text { (Degree) }\end{array}$ & \multicolumn{2}{c}{ Maximum Rotation along Axes (Degree) } \\
\cline { 2 - 3 } & $\mathbf{x}$ & $\mathbf{y}$ \\
\hline 0 & 18,15 & 17,53 \\
60 & 27,9 & 21,6 \\
90 & 51,3 & 21,7 \\
120 & 62,5 & 33,7 \\
& 34,6 & 15,5 \\
\hline
\end{tabular}

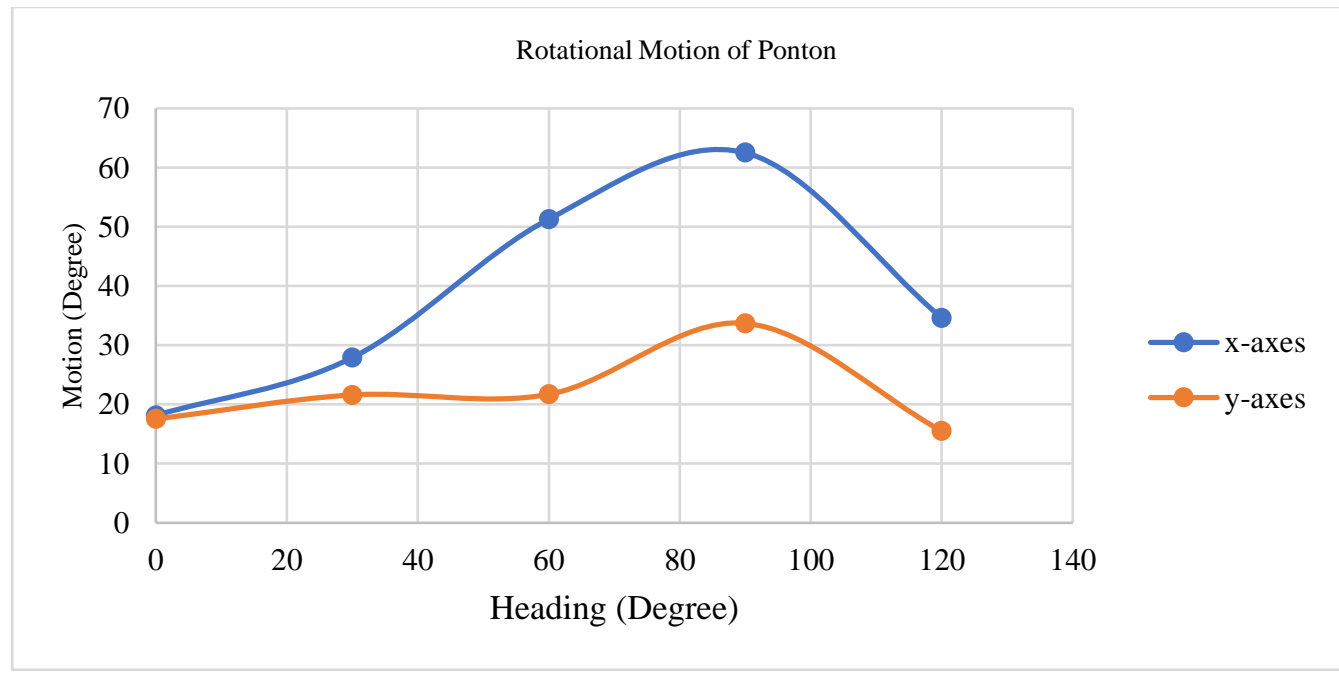

Figure. 16. Rotational motion along $\mathrm{X}$ and $\mathrm{Y}$ axis of Pontoon with mooring system.

Figure. 16 shows that the highest degree of motion occurred at $62,5^{\circ}$ along the $\mathrm{x}$-axis when the load is coming from $90^{\circ}$ heading; this means that the pontoon is experiencing rolling. The lowest degree of motion occurred at $15,5^{\circ}$ along the y-axis when a load is coming from $120^{\circ}$ heading, which means that the ponton experienced pitching.

\section{CONCLUSION}

Based on the simulation results on the design variation with a hexagonal pontoon for wave energy conversion system, conclusions are drawn as listed below:

1. Model Variation 1 of the wave energy conversion system is the most effective design compared to Variation 2 and 3. The addition of floaters to the hexagonal pontoon with a longer arm tends to have a higher value of both translational and rotational motion. Highest RAOs reached during seakeeping simulation for surge, sway, heave, roll, pitch and yaw is $0,998 \mathrm{~m} / \mathrm{m}$ in heading $90^{\circ} ; 1,684$ $\mathrm{m} / \mathrm{m}$ in heading $60^{\circ} ; 0,998 \mathrm{~m} / \mathrm{m}$ in heading $90^{\circ} ; 22,13$ $\mathrm{deg} / \mathrm{m}$ in heading $60^{\circ} ; 21,65 \mathrm{deg} / \mathrm{m}$ in heading $0^{\circ}$; and $77,2 \mathrm{deg} / \mathrm{m}$ in heading $120^{\circ}$ consecutively.

2. A single point mooring system is suitable for this design because after moored, the pontoon is still able to have rotational and translational motion along the $\mathrm{x}$ and $\mathrm{y}$-axis. Based on the analysis of mooring simulation results, the furthest excursion occurred when the load is coming from $0^{\circ}$ heading at 5,1 meters along $\mathrm{X}$-axis while the shortest excursion occurred when the load is coming from $120^{\circ}$ heading at 1,5 meters along $\mathrm{Y}$-axis. Rolling motion reached $62,5^{\circ}$ along the $\mathrm{x}$-axis when the load is coming from $90^{\circ}$ heading while pitching reached $15,5^{\circ}$ along the $\mathrm{y}$-axis when the load is coming from $120^{\circ}$ heading. 
International Journal of Marine Engineering Innovation and Research, Vol. 5(2), Jun. 2020. 68-80

(pISSN: 2541-5972, eISSN: 2548-1479)

\section{REFERENCES}

[1] T. Kåberger, "Progress of renewable electricity replacing fossil fuels," Glob. Energy Interconnect., vol. 1, no. 1, p. 5, 2018.

[2] N. P. Purba et al., "Suitable locations of ocean renewable energy (ORE) in Indonesia region-GIS approached," Energy Procedia, vol. 65, pp. 230-238, 2015.

[3] R. E. Harris, L. Johanning, and J. Wolfram, "Mooring systems for wave energy converters: A review of design issues and choices," p. 11.

[4] A. Baidowi and A. R. Suwandi, "ANALYSIS OF THE DEEP WATER MOORING SYSTEM PLATFORM," vol. 57, p. 9.

[5] A. Baidowi, I. S. Arief, and A. Munib, "Analysis of the Motion Response on the Cylindrical Platform of the Deep Sea," Int. J. Mar. Eng. Innov. Res., vol. 3, no. 4, 2019.

[6] A. Baidowi, S. Semin, E. S. Koenhardono, A. Amiadji, and F. Ainin, "Motion Response of a Novel Platform of Vertical Axis Marine Current Turbine," Int. Rev. Mech. Eng. IREME, vol. 13, no. 12, p. 710, Dec. 2019, doi: 10.15866/ireme.v13i12.18035.

[7] S. P. Neill and M. R. Hashemi, "Wave Energy," in Fundamentals of Ocean Renewable Energy, Elsevier, 2018, pp. 107-140.

[8] Z. Liu, Z. Han, H. Shi, and W. Yang, "Experimental study on multi-level overtopping wave energy convertor under regular wave conditions," Int. J. Nav. Archit. Ocean Eng., vol. 10, no. 5, pp. 651-659, Sep. 2018, doi: 10.1016/j.ijnaoe.2017.10.004.

[9] S. Kim, J. Lee, D. Kang, and S. Lee, "Motion characteristics of a floating wave energy converter with wave activating body type," Int. J. Nav. Archit. Ocean Eng., vol. 11, no. 1, pp. 244-255, Jan. 2019, doi: 10.1016/j.ijnaoe.2018.04.005.

[10] T. Aderinto and H. Li, "Review on Power Performance and Efficiency of Wave Energy Converters," Energies, vol. 12, no. 22, p. 4329, Nov. 2019, doi: 10.3390/en12224329.

[11] D. T. Brown, "Mooring Systems," in Handbook of Offshore Engineering, Elsevier, 2005, pp. 663-708.

[12] A. Pecher and J. P. Kofoed, Eds., Handbook of Ocean Wave Energy, vol. 7. Cham: Springer International Publishing, 2017.

[13] S. Xu, S. Wang, and C. Guedes Soares, "Review of mooring design for floating wave energy converters," Renew. Sustain. Energy Rev., vol. 111, pp. 595-621, Sep. 2019, doi: 10.1016/j.rser.2019.05.027.

[14] T. Gourlay et al., "Benchmarking of DIFFRAC, FATIMA, HydroSTAR, MOSES, NEMOH, OCTOPUS, PDStrip, RAPID, SEAWAY, SlenderFlow and WAMIT against measured vertical motions of the Duisburg Test Case container ship in shallow water," p. 8, 2019.

[15] T. Y. Tun, "Ship Hull Optimization in Calm Water and Moderate Sea States," p. 102, 2014.

[16] L. Martinelli, P. Ruol, and G. Cortellazzo, "ON MOORING DESIGN OF WAVE ENERGY CONVERTERS: THE SEABREATH APPLICATION," Coast. Eng. Proc., vol. 1, no. 33, p. 3, Oct. 2012, doi: 10.9753/icce.v33.structures.3. 